\title{
Protection afforded by the BNT162b2 and mRNA-1273 COVID-19 vaccines in fully vaccinated cohorts with and without prior infection
}

Laith J. Abu-Raddad, $\mathrm{PhD}^{1,2,3^{*}}$, Hiam Chemaitelly, MSc${ }^{1,2}$, Houssein H. Ayoub, $\mathrm{PhD}^{4}$, Hadi M. Yassine, $\mathrm{PhD}^{5,6}$, Fatiha M. Benslimane, $\mathrm{PhD}^{5,6}$, Hebah A. Al Khatib, $\mathrm{PhD}^{5,6}$, Patrick Tang, MD $\mathrm{PhD}^{7}$, Mohammad R. Hasan ${ }^{7}$, Peter Coyle, $\mathrm{MD}^{5,8,9}$, Zaina Al Kanaani, $\mathrm{PhD}^{8}$, Einas Al Kuwari, $\mathrm{MD}^{8}$, Andrew Jeremijenko, $\mathrm{MD}^{8}$, Anvar Hassan Kaleeckal, $\mathrm{MSc}^{8}$, Ali Nizar Latif, $\mathrm{MD}^{8}$, Riyazuddin Mohammad Shaik, $\mathrm{MSc}^{8}$, Hanan F. Abdul Rahim, $\mathrm{PhD}^{10}$, Gheyath K. Nasrallah, $\mathrm{PhD}^{5,6}$, Mohamed Ghaith Al Kuwari, MD ${ }^{11}$, Adeel A. Butt, MBBS MS ${ }^{3,8}$, Hamad Eid Al Romaihi, $\mathrm{MD}^{12}$, Mohamed H. Al-Thani, $\mathrm{MD}^{12}$, Abdullatif Al Khal, $\mathrm{MD}^{8}$, and Roberto Bertollini, $\mathrm{MD} \mathrm{MPH}^{12}$

${ }^{1}$ Infectious Disease Epidemiology Group, Weill Cornell Medicine-Qatar, Cornell University, Doha, Qatar

${ }^{2}$ World Health Organization Collaborating Centre for Disease Epidemiology Analytics on HIV/AIDS, Sexually Transmitted Infections, and Viral Hepatitis, Weill Cornell Medicine-Qatar, Cornell University, Qatar Foundation - Education City, Doha, Qatar

${ }^{3}$ Department of Population Health Sciences, Weill Cornell Medicine, Cornell University, New York, New York, USA

${ }^{4}$ Department of Mathematics, Statistics, and Physics, Qatar University, Doha, Qatar

${ }^{5}$ Biomedical Research Center, Member of QU Health, Qatar University, Doha, Qatar

${ }^{6}$ Department of Biomedical Science, College of Health Sciences, Member of QU Health, Qatar University, Doha, Qatar

${ }^{7}$ Department of Pathology, Sidra Medicine, Doha, Qatar

${ }^{8}$ Hamad Medical Corporation, Doha, Qatar

${ }^{9}$ Wellcome-Wolfson Institute for Experimental Medicine, Queens University, Belfast, United Kingdom

${ }^{10}$ College of Health Sciences, QU Health, Qatar University, Doha, Qatar

${ }^{11}$ Primary Health Care Corporation, Doha, Qatar

${ }^{12}$ Ministry of Public Health, Doha, Qatar

Word count: Abstract: 165 words, Main Text: 1,007 words.

Number of tables: 1 .

Number of figures: 3 .

Running head: Effect of prior SARS-CoV-2 infection on vaccine protection.

Keywords: SARS-CoV-2; COVID-19; prior infection; vaccine; cohort study; immunity; epidemiology.

*Correspondence to Professor Laith J. Abu-Raddad, E-mail: 1ja2002@qatar-med.cornell.edu. 
medRxiv preprint doi: https://doi.org/10.1101/2021.07.25.21261093; this version posted July 26, 2021. The copyright holder for this preprint (which was not certified by peer review) is the author/funder, who has granted medRxiv a license to display the preprint in perpetuity.

All rights reserved. No reuse allowed without permission.

\begin{abstract}
Effect of prior SARS-CoV-2 infection on vaccine protection remains poorly understood. Here, we investigated whether persons vaccinated after a prior infection have better protection against future infection than those vaccinated without prior infection. Effect of prior infection was assessed in Qatar's population, where the Alpha (B.1.1.7) and Beta (B.1.351) variants dominate incidence, using two national retrospective, matched-cohort studies, one for the BNT162b2 (Pfizer-BioNTech) vaccine, and one for the mRNA-1273 (Moderna) vaccine. Incidence rates of infection among BNT162b2-vaccinated persons, with and without prior infection, were estimated, respectively, at 1.66 (95\% CI: 1.26-2.18) and 11.02 (95\% CI: 9.90-12.26) per 10,000 person-weeks. The incidence rate ratio was 0.15 (95\% CI: 0.11-0.20). Analogous incidence rates among mRNA-1273-vaccinated persons were estimated at 1.55 (95\% CI: 0.86-2.80) and 1.83 (95\% CI: $1.07-3.16)$ per 10,000 person-weeks. The incidence rate ratio was 0.85 (95\% CI: 0.342.05). Prior infection enhanced protection of those BNT162b2-vaccinated, but not those mRNA1273-vaccinated. These findings may have implications for dosing, interval between doses, and potential need for booster vaccination.
\end{abstract}


medRxiv preprint doi: https://doi.org/10.1101/2021.07.25.21261093; this version posted July 26, 2021. The copyright holder for this preprint (which was not certified by peer review) is the author/funder, who has granted medRxiv a license to display the preprint in perpetuity.

All rights reserved. No reuse allowed without permission.

\section{Main text}

Effect of prior acute respiratory syndrome coronavirus 2 (SARS-CoV-2) infection on vaccine protection against acquisition of infection remains poorly understood ${ }^{1-3}$. Qatar launched Coronavirus Disease 2019 (COVID-19) immunization in December 21, 2020, first using the BNT162b2 ${ }^{4}$ (Pfizer-BioNTech) vaccine and subsequently adding the mRNA-12735 (Moderna) vaccine $^{6,7}$. As vaccination was scaled up following the FDA-approved protocol, the country experienced two back-to-back SARS-CoV-2 waves from January-June, 2021, which were dominated by the $\operatorname{Alpha}^{8}$ (B.1.1.7) and $\operatorname{Beta}^{8}$ (B.1.351) variants ${ }^{6,7,9-11}$ (Methods). This provided an opportunity to assess whether persons vaccinated after a prior SARS-CoV-2 infection have better protection against future infection than those vaccinated without prior infection.

Leveraging the national, federated databases that have captured all SARS-CoV-2 vaccinations and PCR testing since the epidemic onset (Methods), we investigated this question using two retrospective, matched-cohort studies. We compared incidence of documented SARS-CoV-2 infection in the national cohort of individuals who completed $\geq 14$ days after the second BNT162b2 vaccine dose, but who had experienced a prior PCR-confirmed infection, with incidence among individuals who completed $\geq 14$ days after the second BNT162b2 dose, but who had not experienced a prior infection, between December 21, 2020-June 6, 2021 (Figure 1). The same comparison was made for the mRNA-1273 vaccine (Figure 2). Cohorts were matched in a 1:1 ratio by sex, 5-year age group, nationality, and calendar week of the first vaccine dose, to control for differences in exposure risk ${ }^{12,13}$ and variant exposure ${ }^{6,7,9-11}$. Reporting of the study followed the STROBE guidelines (Supplementary Table 1).

Figures 1-2 show the process for identifying infections in these cohorts, and Table 1 presents their demographic characteristics. Using the Kaplan-Meier estimator ${ }^{14}$, cumulative infection 
medRxiv preprint doi: https://doi.org/10.1101/2021.07.25.21261093; this version posted July 26, 2021. The copyright holder for this preprint (which was not certified by peer review) is the author/funder, who has granted medRxiv a license to display the preprint in perpetuity.

All rights reserved. No reuse allowed without permission.

incidence among BNT162b2-vaccinated persons, with and without prior infection, was estimated at $0.14 \%$ (95\% CI: 0.11-0.19\%) and 0.93\% (95\% CI: 0.83-1.04\%), respectively, after 63 days of follow-up (Figure 1). Incidence rates of infection were estimated, respectively, at 1.66 (95\% CI: 1.26-2.18) and 11.02 (95\% CI: 9.90-12.26) per 10,000 person-weeks. The incidence rate ratio was estimated at 0.15 (95\% CI: 0.11-0.20).

Cumulative infection incidence among mRNA-1273-vaccinated persons, with and without prior infection, was estimated at $0.06 \%$ (95\% CI: $0.03-0.12 \%$ ) and $0.08 \%$ (95\% CI: $0.04-0.15 \%$, respectively, after 63 days of follow-up (Figure 1). Incidence rates were estimated, respectively, at 1.55 (95\% CI: $0.86-2.80)$ and 1.83 (95\% CI: $1.07-3.16)$ per 10,000 person-weeks. The incidence rate ratio was estimated at 0.85 (95\% CI: 0.34-2.05).

Infection incidence was low in these cohorts during a time of intense incidence in Qatar ${ }^{6,7,15}$, indicating that both vaccines were highly effective against the Alpha and Beta variants ${ }^{6,7}$, which dominated incidence ${ }^{9}$ (Methods). Still, prior infection of those BNT162b2-vaccinated further enhanced protection and reduced the incidence rate by $85 \%$ (6.6-fold) compared to those without prior infection. No evidence for such an effect was found for those mRNA-1273-vaccinated.

These findings are perhaps explained by the observed differences in effectiveness of these two vaccines against the Alpha and Beta variants, estimated in Qatar at 89.5\% (95\% CI: 85.9-92.3\%) and $75.0 \%$ (95\% CI: 70.5-78.9\%) for BNT162b2, respectively ${ }^{6}$, and at 100\% (95\% CI: 91.8$100.0 \%$ ) and $96.4 \%$ (95\% CI: 91.9-98.7\%) for mRNA-1273, respectively ${ }^{7}$.

The differences in effectiveness could have risen for a variety of reasons, such as differences in dosing, interval between doses, or the biology of both vaccines and their mechanisms of action. The dose of each of these two vaccines differed-it was $30-\mu \mathrm{g}$ per dose for BNT162b2 ${ }^{4}$ and 100 $\mu \mathrm{g}$ per dose for mRNA- $1273^{5}$. This may have resulted in a more activated immune response for 
medRxiv preprint doi: https://doi.org/10.1101/2021.07.25.21261093; this version posted July 26, 2021. The copyright holder for this preprint (which was not certified by peer review) is the author/funder, who has granted medRxiv a license to display the preprint in perpetuity.

All rights reserved. No reuse allowed without permission.

the mRNA-1273 vaccine than the BNT162b2 vaccine, and made the existence of prior immunity due to natural infection of no additional benefit for the mRNA-1273 vaccine. The interval between doses also differed and was one week longer for mRNA-1273 ${ }^{5}$. Evidence suggests that a longer dose interval could be associated with improved protection after receiving the second $\operatorname{dose}^{16}$

Limitations include identifying prior infection based on a record of a PCR-positive result, thereby missing those who may have been infected, but were unaware of their infection, or who did not seek testing by PCR to document the infection. Misclassification of prior infection status could lead to underestimation of the effect size of prior infection on vaccine protection. Depletion of the cohorts with prior infection due to COVID-19 mortality at time of the prior infection may have biased these cohorts toward healthier individuals with stronger immune responses. However, COVID-19 mortality has been low in Qatar's predominantly young and working-age population ${ }^{12,17}$, and no evidence for such bias was found in the mRNA-1273 vaccine results, where the incidence rate was similar for those with and without prior infection.

We assessed risk of only documented infections, but other infections may have occurred and gone undocumented, perhaps because of minimal/mild or no symptoms. Our cohorts predominantly included working-age adults; therefore, results may not necessarily be generalizable to other population groups, such as children or the elderly. Matching was done for age, sex, nationality, and calendar week of the first vaccine dose, and could not be done for other factors, such as comorbidities or additional socio-demographic factors, as these were not available to study investigators. However, matching by age and sex may have served as a proxy given that co-morbidities are associated with older age and may be different between women and 
medRxiv preprint doi: https://doi.org/10.1101/2021.07.25.21261093; this version posted July 26, 2021. The copyright holder for this preprint (which was not certified by peer review) is the author/funder, who has granted medRxiv a license to display the preprint in perpetuity.

All rights reserved. No reuse allowed without permission.

men. Matching by nationality may have also captured some of the occupational risk given the distribution of the labor force in Qatar ${ }^{18-20}$.

Imperfect assay sensitivity and specificity of PCR or antibody testing could have affected current or prior infection ascertainment. However, all PCR and serological testing was performed with extensively used, investigated, and validated commercial platforms with essentially $100 \%$ sensitivity and specificity (Methods). Unlike blinded, randomized clinical trials, the investigated observational cohorts were neither blinded nor randomized.

Our results demonstrate low infection incidence among those vaccinated with BNT162b2 or mRNA-1273, but among those vaccinated with BNT162b2, protection against infection was further enhanced and infection incidence was further reduced by prior infection. In contrast, those vaccinated with mRNA-1273 were as well protected as those who received the vaccine after a prior infection. These findings may have implications for the potential need of a booster vaccination. 
medRxiv preprint doi: https://doi.org/10.1101/2021.07.25.21261093; this version posted July 26, 2021. The copyright holder for this preprint (which was not certified by peer review) is the author/funder, who has granted medRxiv a license to display the preprint in perpetuity.

All rights reserved. No reuse allowed without permission.

\section{Acknowledgements}

We acknowledge the many dedicated individuals at Hamad Medical Corporation, the Ministry of Public Health, the Primary Health Care Corporation, and the Qatar Biobank for their diligent efforts and contributions to make this study possible. The authors are grateful for support from the Biomedical Research Program, the Biostatistics, Epidemiology, and Biomathematics Research Core, and the Genomics Core, all at Weill Cornell Medicine-Qatar, as well as for support provided by the Ministry of Public Health and Hamad Medical Corporation. The authors are also grateful for the Qatar Genome Programme for supporting the viral genome sequencing. The funders of the study had no role in study design, data collection, data analysis, data interpretation, or writing of the article. Statements made herein are solely the responsibility of the authors.

\section{Author contributions}

LJA conceived and co-designed the study, led the statistical analyses, and co-wrote the first draft of the article. HC co-designed the study, performed the statistical analyses, and co-wrote the first draft of the article. All authors contributed to data collection and acquisition, database development, discussion and interpretation of the results, and to the writing of the manuscript. All authors have read and approved the final manuscript.

\section{Competing interests}

Dr. Butt has received institutional grant funding from Gilead Sciences unrelated to the work presented in this paper. Otherwise, we declare no competing interests. 
medRxiv preprint doi: https://doi.org/10.1101/2021.07.25.21261093; this version posted July 26, 2021. The copyright holder for this preprint (which was not certified by peer review) is the author/funder, who has granted medRxiv a license to display the preprint in perpetuity.

\section{References}

1. Reynolds, C.J., et al. Prior SARS-CoV-2 infection rescues B and T cell responses to variants after first vaccine dose. Science (2021).

2. Muena, N.A., et al. Long-lasting neutralizing antibody responses in SARS-CoV-2 seropositive individuals are robustly boosted by immunization with the CoronaVac and BNT162b2 vaccines. medRxiv (2021).

3. Letizia, A.G., et al. SARS-CoV-2 seropositivity and subsequent infection risk in healthy young adults: a prospective cohort study. Lancet Respir Med 9, 712-720 (2021).

4. Polack, F.P., et al. Safety and Efficacy of the BNT162b2 mRNA Covid-19 Vaccine. $N$ Engl J Med (2020).

5. Baden, L.R., et al. Efficacy and Safety of the mRNA-1273 SARS-CoV-2 Vaccine. $N$ Engl J Med 384, 403-416 (2021).

6. Abu-Raddad, L.J., Chemaitelly, H., Butt, A.A. \& National Study Group for Covid-19 Vaccination. Effectiveness of the BNT162b2 Covid-19 Vaccine against the B.1.1.7 and B.1.351 Variants. $N$ Engl J Med (2021).

7. Chemaitelly, H., et al. mRNA-1273 COVID-19 vaccine effectiveness against the B.1.1.7 and B.1.351 variants and severe COVID-19 disease in Qatar. Nat Med (2021).

8. World Health Organization. Tracking SARS-CoV-2 variants. Available from: https://www.who.int/en/activities/tracking-SARS-CoV-2-variants/. Accessed on: June 5, 2021. (2021).

9. National Project of Surveillance for Variants of Concern and Viral Genome Sequencing. Qatar viral genome sequencing data. Data on randomly collected samples. https://www.gisaid.org/phylodynamics/global/nextstrain/. (2021).

10. Benslimane, F.M., et al. One year of SARS-CoV-2: Genomic characterization of COVID-19 outbreak in Qatar. medRxiv, 2021.2005.2019.21257433 (2021).

11. Hasan, M.R., et al. Real-Time SARS-CoV-2 Genotyping by High-Throughput Multiplex PCR Reveals the Epidemiology of the Variants of Concern in Qatar. medRxiv, 2021.2007.2018.21260718 (2021).

12. Abu-Raddad, L.J., et al. Characterizing the Qatar advanced-phase SARS-CoV-2 epidemic. Scientific Reports 11, 6233 (2021).

13. Ayoub, H.H., et al. Mathematical modeling of the SARS-CoV-2 epidemic in Qatar and its impact on the national response to COVID-19. J Glob Health 11, 05005 (2021).

14. Kaplan, E.L. \& Meier, P. Nonparametric estimation from incomplete observations. The Journal of the American Statistical Association 53, 457-481 (1958).

15. Chemaitelly, H., et al. Reinfections with the SARS-CoV-2 B.1.351 variant and efficacy of natural immunity against reinfection under review at New England Journal of Medicine (2021).

16. Voysey, M., et al. Single-dose administration and the influence of the timing of the booster dose on immunogenicity and efficacy of ChAdOx1 nCoV-19 (AZD1222) vaccine: a pooled analysis of four randomised trials. Lancet 397, 881-891 (2021).

17. Seedat, S., et al. SARS-CoV-2 infection hospitalization, severity, criticality, and fatality rates. medRxiv 2020.11.29.20240416 (non-peer-reviewed preprint) (2020).

18. Jeremijenko, A., et al. Herd Immunity against Severe Acute Respiratory Syndrome Coronavirus 2 Infection in 10 Communities, Qatar. Emerg Infect Dis 27, 1343-1352 (2021). 
medRxiv preprint doi: https://doi.org/10.1101/2021.07.25.21261093; this version posted July 26, 2021. The copyright holder for this preprint (which was not certified by peer review) is the author/funder, who has granted medRxiv a license to display the preprint in perpetuity.

All rights reserved. No reuse allowed without permission.

19. Al-Thani, M.H., et al. SARS-CoV-2 infection is at herd immunity in the majority segment of the population of Qatar. Open Forum Infectious Diseases (2021).

20. Coyle, P.V., et al. SARS-CoV-2 seroprevalence in the urban population of Qatar: An analysis of antibody testing on a sample of 112,941 individuals. iScience, 102646 (2021).

21. World Health Organization. COVID-19 clinical management: living guidance. Available from: https://www.who.int/publications/i/item/WHO-2019-nCoV-clinical-2021-1. Accessed on: May 15, 2021. (2021).

22. World Health Organization. International guidelines for certification and classification (coding) of COVID-19 as cause of death. Available from:

https://www.who.int/classifications/icd/Guidelines_Cause_of_Death_COVID-1920200420-EN.pdf?ua=1. Document Number: WHO/HQ/DDI/DNA/CAT. Accessed on May 15, 2021. (2020).

23. Planning and Statistics Authority-State of Qatar. Qatar Monthly Statistics. Available from: https://www.psa.gov.qa/en/pages/default.aspx. Accessed on: May 26, 2020. (2020).

24. Vogels, C., Fauver, J. \& Grubaugh, N. Multiplexed RT-qPCR to screen for SARS-COV2 B.1.1.7, B.1.351, and P.1 variants of concern V.3. dx.doi.org/10.17504/protocols.io.br9vm966. (2021).

25. Abu-Raddad, L.J., et al. Assessment of the risk of SARS-CoV-2 reinfection in an intense re-exposure setting. Clin Infect Dis (2020).

26. Abu-Raddad, L.J., et al. SARS-CoV-2 antibody-positivity protects against reinfection for at least seven months with 95\% efficacy. EClinicalMedicine 35, 100861 (2021).

27. Al Kuwari, H.M., et al. Epidemiological investigation of the first 5685 cases of SARSCoV-2 infection in Qatar, 28 February-18 April 2020. BMJ Open 10, e040428 (2020).

28. Ayoub, H.H., et al. Epidemiological impact of prioritising SARS-CoV-2 vaccination by antibody status: mathematical modelling analyses. BMJ Innovations, bmjinnov-2021000677 (2021).

29. Butt, A.A., et al. Hospital admission rates, length of stay, and in-hospital mortality for common acute care conditions in COVID-19 vs. pre-COVID-19 era. Public Health 189, 6-11 (2020).

30. Saththasivam, J., et al. COVID-19 (SARS-CoV-2) outbreak monitoring using wastewater-based epidemiology in Qatar. Sci Total Environ 774, 145608 (2021).

31. Seedat, S., et al. SARS-CoV-2 infection hospitalization, severity, criticality, and fatality rates. medRxiv 2020.11.29.20240416 (2020).

32. Abu-Raddad, L.J., et al. Two prolonged viremic SARS-CoV-2 infections with conserved viral genome for two months. Infect Genet Evol 88, 104684 (2020).

33. Abu-Raddad, L.J., et al. Pfizer-BioNTech mRNA BNT162b2 Covid-19 vaccine protection against variants of concern after one versus two doses. J Travel Med (2021).

34. Nasrallah, G.K., et al. Analytic comparison between three high-throughput commercial SARS-CoV-2 antibody assays reveals minor discrepancies in a high-incidence population. Sci Rep 11, 11837 (2021).

35. Thermo Fisher Scientific. TaqPath ${ }^{\mathrm{TM}}$ COVID-19 CE-IVD RT-PCR Kit instructions for use. Available from: https://assets.thermofisher.com/TFSAssets/LSG/manuals/MAN0019215_TaqPathCOVID-19_CE-IVD_RTPCR\%20Kit_IFU.pdf. Accessed on December 02, 2020. (2020). 
medRxiv preprint doi: https://doi.org/10.1101/2021.07.25.21261093; this version posted July 26, 2021. The copyright holder for this preprint

(which was not certified by peer review) is the author/funder, who has granted medRxiv a license to display the preprint in perpetuity.

All rights reserved. No reuse allowed without permission.

36. Kalikiri, M.K.R., et al. High-throughput extraction of SARS-CoV-2 RNA from nasopharyngeal swabs using solid-phase reverse immobilization beads. medRxiv, 2020.2004.2008.20055731 (2020).

37. Kubina, R. \& Dziedzic, A. Molecular and Serological Tests for COVID-19 a Comparative Review of SARS-CoV-2 Coronavirus Laboratory and Point-of-Care Diagnostics. Diagnostics (Basel) 10(2020).

38. US Food and Drug Administration. Cobas® SARS-CoV-2: Qualitative assay for use on the cobas ${ }^{\circledR} 6800 / 8800$ Systems. Avilable from:

https://www.fda.gov/media/136049/download. Accessed on: December 02, 2020. (2020).

39. Muench, P., et al. Development and Validation of the Elecsys Anti-SARS-CoV-2 Immunoassay as a Highly Specific Tool for Determining Past Exposure to SARS-CoV-2. J Clin Microbiol 58(2020).

40. The Roche Group. Roche's COVID-19 antibody test receives FDA Emergency Use Authorization and is available in markets accepting the CE mark. Available from: https://www.roche.com/media/releases/med-cor-2020-05-03.htm. Accessed on: June 5, 2020. (2020).

41. Oved, K., et al. Multi-center nationwide comparison of seven serology assays reveals a SARS-CoV-2 non-responding seronegative subpopulation. EClinicalMedicine 29, 100651 (2020).

42. StataCorp. Stata Statistical Software: Release 17. College Station, TX: StataCorp LLC. (2021). 
Figure 1. The process for identifying SARS-CoV-2 infections in the national cohort of individuals who completed $\geq 14$ days after the second BNT162b2 vaccine dose and who had experienced a PCR-confirmed infection before the first dose, compared with the process for identifying SARS-CoV-2 infections in the national cohort of individuals who completed $\geq 14$ days after the second BNT162b2 vaccine dose, but who had experienced no PCR-confirmed infection before the first dose. Cohorts were matched in a 1:1 ratio by sex, 5-year age group, nationality, and calendar week of the first vaccine dose. Total follow-up time among BNT162b2-vaccinated persons, with and without prior infection, was $308,086.0$ and $305,891.9$ person-weeks, respectively.

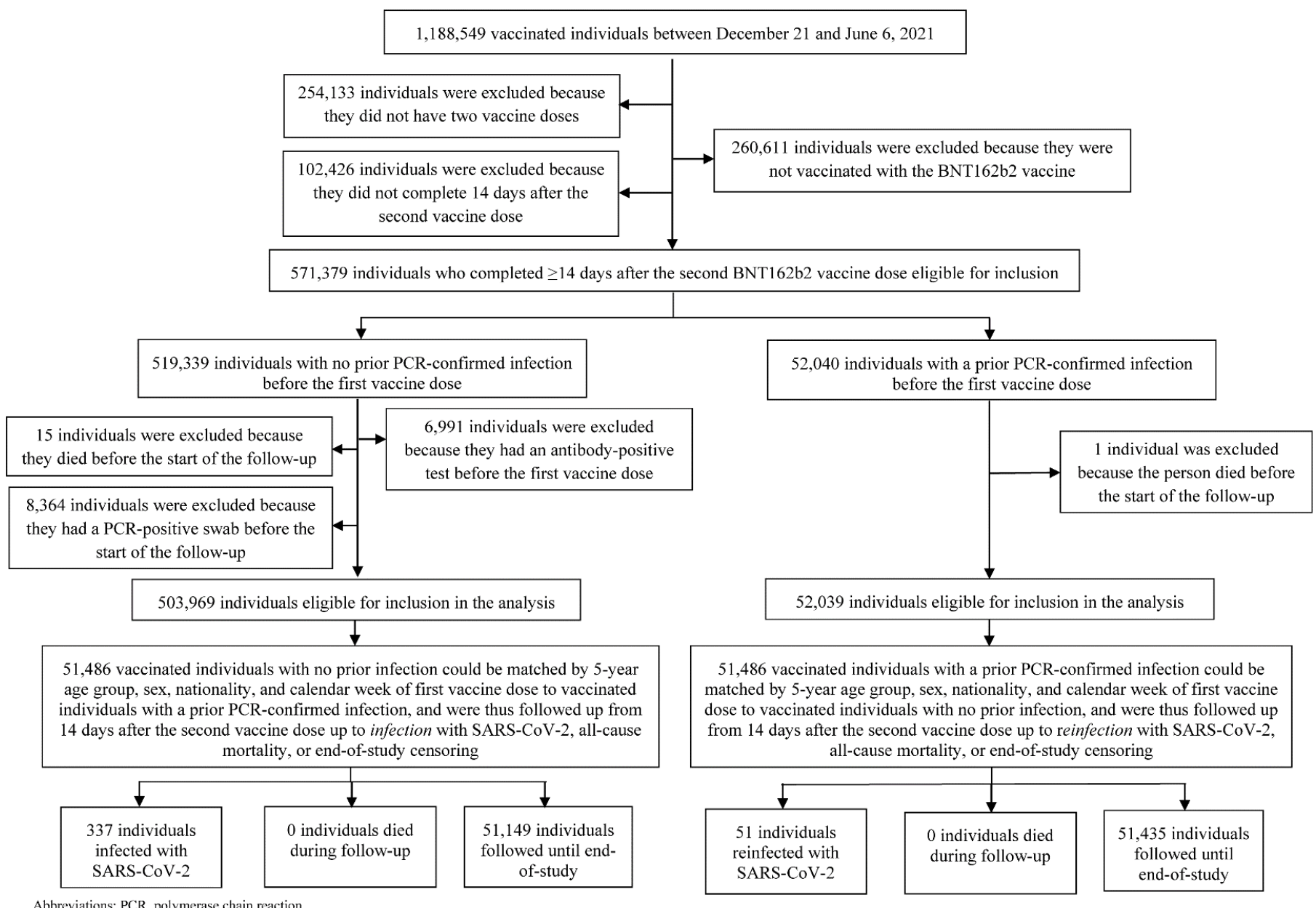


Figure 2. The process for identifying SARS-CoV-2 infections in the national cohort of individuals who completed $\geq 14$ days after the second mRNA-1273 vaccine dose and who had experienced a PCR-confirmed infection before the first dose, compared with the process for identifying SARS-CoV-2 infections in the national cohort of individuals who completed $\geq 14$ days after the second mRNA-1273 vaccine dose, but who had experienced no PCR-confirmed infection before the first dose. Cohorts were matched in a 1:1 ratio by sex, 5-year age group, nationality, and calendar week of the first vaccine dose. Total follow-up time among mRNA-1273-vaccinated persons, with and without prior infection, was 70,729.9 and 70,872 personweeks, respectively.

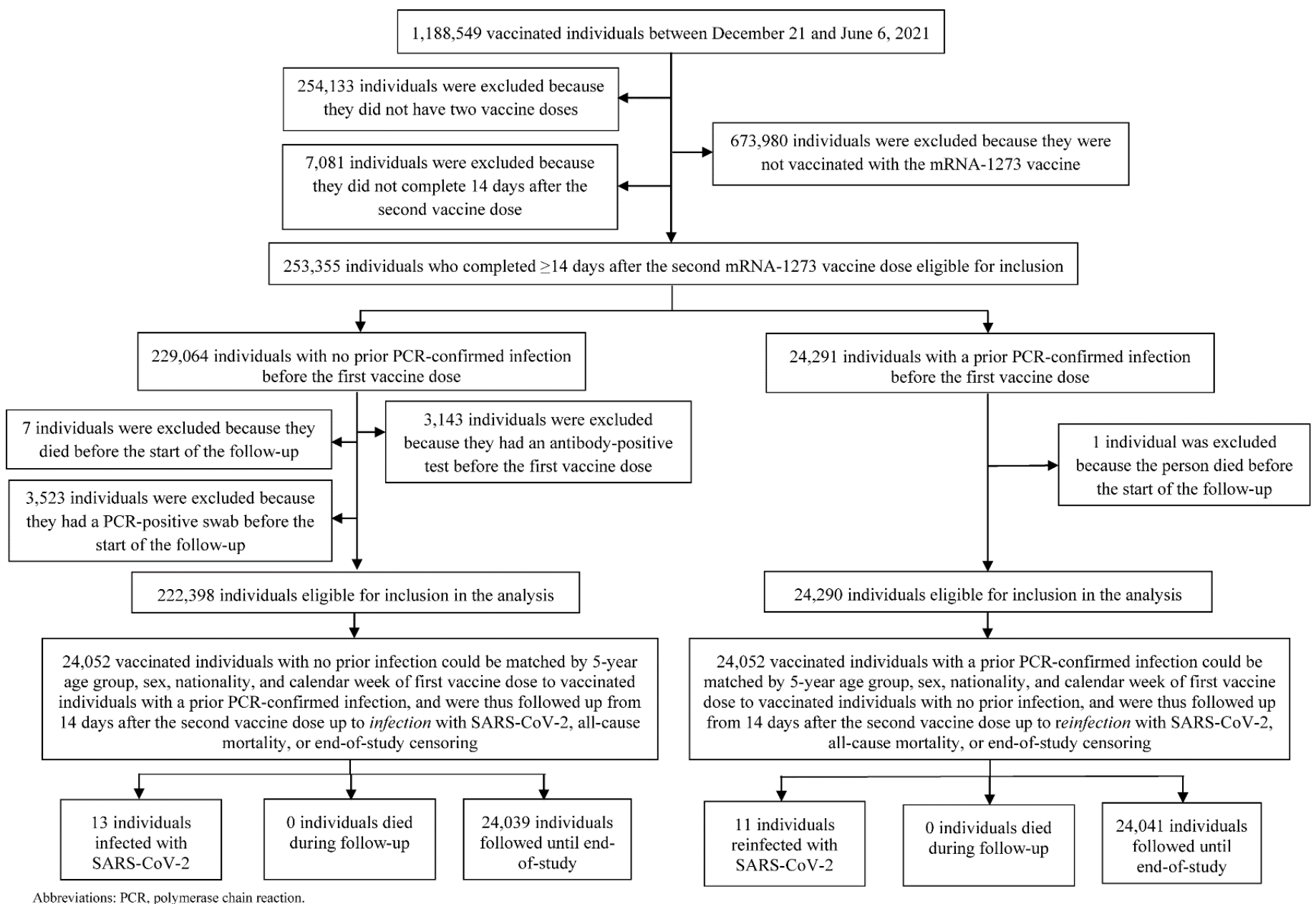


Table 1. Demographic characteristics of matched cohorts that received the BNT162b2 and mRNA-1273 vaccines.

\begin{tabular}{|c|c|c|c|c|c|c|}
\hline \multirow[t]{2}{*}{ Characteristics } & \multicolumn{3}{|c|}{ Vaccination with the BNT162b2 vaccine } & \multicolumn{3}{|c|}{ Vaccination with the mRNA-1273 vaccine } \\
\hline & $\begin{array}{c}\text { Individuals with a } \\
\text { prior PCR-confirmed } \\
\text { infection }\end{array}$ & $\begin{array}{c}\text { Individuals with no } \\
\text { prior PCR-confirmed } \\
\text { infection }\end{array}$ & p-value & $\begin{array}{c}\text { Individuals with a } \\
\text { prior PCR-confirmed } \\
\text { infection }\end{array}$ & $\begin{array}{c}\text { Individuals with no } \\
\text { prior PCR-confirmed } \\
\text { infection }\end{array}$ & p-value \\
\hline $\begin{array}{l}\text { Median age (IQR) - years } \\
\text { Age group - no. }(\%)\end{array}$ & $39(32-48)$ & $39(32-48)$ & 0.972 & $40(33-47)$ & $40(33-47)$ & 0.869 \\
\hline$<20$ years & $1,573(3.1)$ & $1,573(3.1)$ & 1.000 & $194(0.8)$ & $194(0.8)$ & 1.000 \\
\hline $20-29$ years & $7,282(14.1)$ & $7,282(14.1)$ & & $3,481(14.5)$ & $3,481(14.5)$ & \\
\hline $30-39$ years & $18,027(35.0)$ & $18,027(35.0)$ & & $8,216(34.2)$ & $8,216(34.2)$ & \\
\hline $40-49$ years & $13,593(26.4)$ & $13,593(26.4)$ & & $7,972(33.1)$ & $7,972(33.1)$ & \\
\hline $50-59$ years & $7,468(14.5)$ & $7,468(14.5)$ & & $3,368(14.0)$ & $3,368(14.0)$ & \\
\hline $60-69$ years & $2,830(5.5)$ & $2,830(5.5)$ & & $704(2.9)$ & $704(2.9)$ & \\
\hline $70+$ years & $713(1.4)$ & $713(1.4)$ & & $117(0.5)$ & $117(0.5)$ & \\
\hline \multicolumn{7}{|l|}{ Sex } \\
\hline Male & $36,970(71.8)$ & $36,970(71.8)$ & 1.000 & $18,697(77.7)$ & $18,697(77.7)$ & 1.000 \\
\hline Female & $14,516(28.2)$ & $14,516(28.2)$ & & $5,355(22.3)$ & $5,355(22.3)$ & \\
\hline \multicolumn{7}{|l|}{ Nationality $^{\dagger}$} \\
\hline Bangladeshi & $3,728(7.2)$ & $3,728(7.2)$ & 1.000 & $2,066(8.6)$ & $2,066(8.6)$ & 1.000 \\
\hline Egyptian & $3,470(6.7)$ & $3,470(6.7)$ & & $1,748(7.3)$ & $1,748(7.3)$ & \\
\hline Filipino & $4,792(9.3)$ & $4,792(9.3)$ & & $2,435(10.1)$ & $2,435(10.1)$ & \\
\hline Indian & $13,033(25.3)$ & $13,033(25.3)$ & & $8,180(34.0)$ & $8,180(34.0)$ & \\
\hline Nepalese & $4,570(8.9)$ & $4,570(8.9)$ & & $2,730(11.4)$ & $2,730(11.4)$ & \\
\hline Pakistani & $1,892(3.7)$ & $1,892(3.7)$ & & $1,105(4.6)$ & $1,105(4.6)$ & \\
\hline Qatari & $9,700(18.8)$ & $9,700(18.8)$ & & $1,047(4.4)$ & $1,047(4.4)$ & \\
\hline Sri Lankan & $1,490(2.9)$ & $1,490(2.9)$ & & $1,114(4.6)$ & $1,114(4.6)$ & \\
\hline Sudanese & $1,259(2.5)$ & $1,259(2.5)$ & & $481(2.0)$ & $481(2.0)$ & \\
\hline Other nationalities & $7,552(14.7)^{\$}$ & $7,552(14.7)^{*}$ & & $3,146(13.1)$ & $3,146(13.1)$ & \\
\hline
\end{tabular}

*Cohorts were matched in a 1:1 ratio by sex, 5 -year age group, nationality, and calendar week of first vaccine dose.

Nationalities were chosen to represent the most numerous groups in the population of Qatar.

¥ Individuals who received the BNT162b2 vaccine in Qatar comprised 96 other nationalities, while those who received the mRNA-1273 vaccine represented 78 other nationalities. 
medRxiv preprint doi: https://doi.org/10.1101/2021.07.25.21261093; this version posted July 26, 2021. The copyright holder for this preprint (which was not certified by peer review) is the author/funder, who has granted medRxiv a license to display the preprint in perpetuity.

All rights reserved. No reuse allowed without permission.

Figure 3. Kaplan-Meier curves showing the cumulative incidence of documented SARSCoV-2 infection in the national cohort of individuals who completed $\geq 14$ days after the second vaccine dose and who had a prior PCR-confirmed infection, compared to the cumulative incidence of documented SARS-CoV-2 infection in the matched national cohort of individuals who completed $\geq 14$ days after the second vaccine dose, but without prior PCR-confirmed infection. The curves compare vaccination with $A$ ) the BNT162b2 (PfizerBioNTech) vaccine and B) the mRNA-1273 vaccine. Cohorts were matched in a 1:1 ratio by sex, 5-year age group, nationality, and calendar week of the first vaccine dose. The curves for a longer time of follow up for only the BNT162b2 vaccine are in Supplementary Figure 1. Vaccination with BNT162b2 started few weeks before vaccination with mRNA-1273.

$\mathbf{A}$

Vaccination with BNT162b2
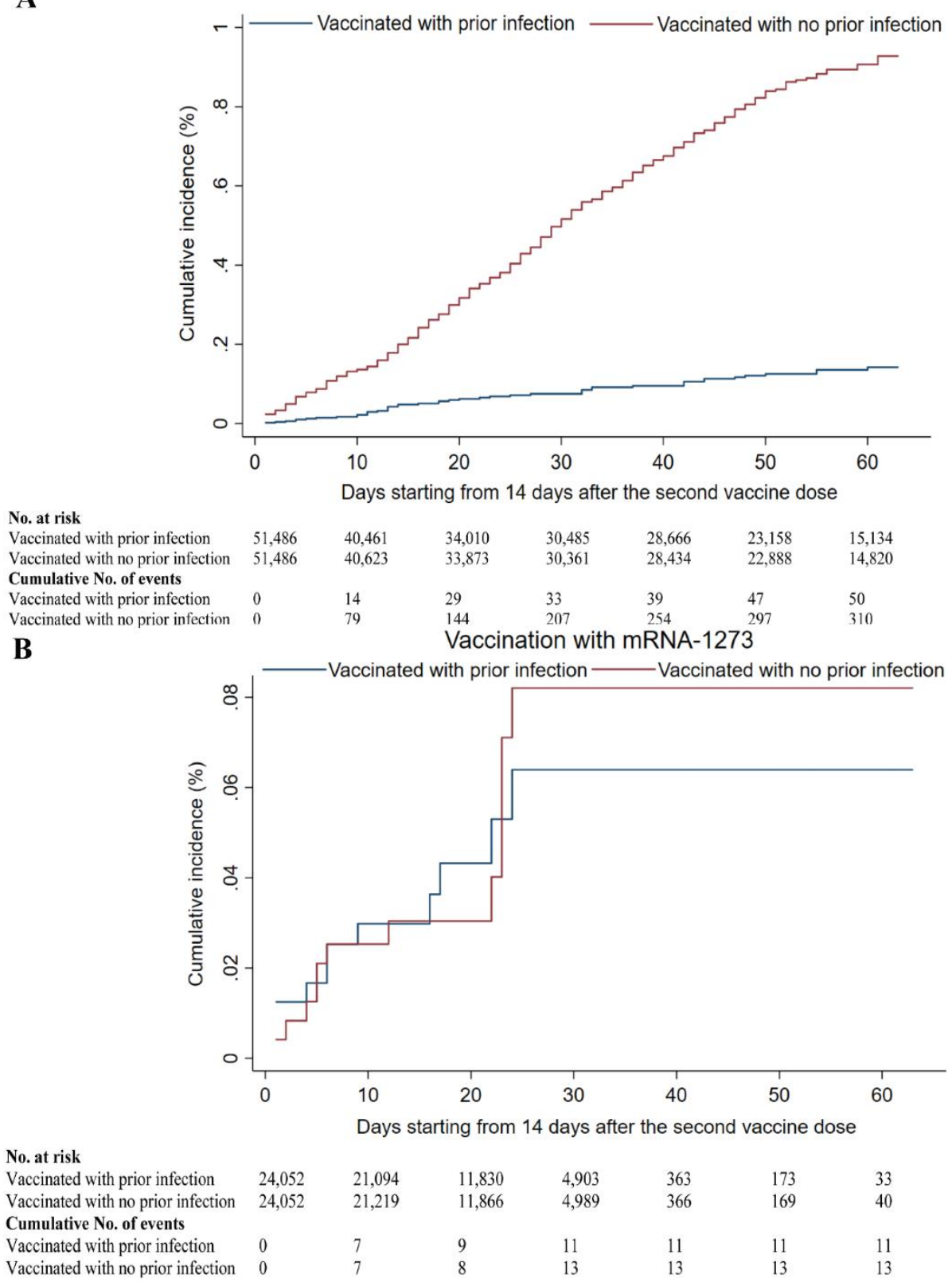
medRxiv preprint doi: https://doi.org/10.1101/2021.07.25.21261093; this version posted July 26, 2021. The copyright holder for this preprint (which was not certified by peer review) is the author/funder, who has granted medRxiv a license to display the preprint in perpetuity.

\section{Methods}

\section{Data sources and study design}

Analyses were conducted using the centralized, integrated, and standardized national severe acute respiratory syndrome coronavirus 2 (SARS-CoV-2) databases compiled at Hamad Medical Corporation (HMC), the main public healthcare provider and the nationally designated provider for all Coronavirus Disease 2019 (COVID-19) healthcare needs. Through a nation-wide digital health information platform, these databases have captured all SARS-CoV-2-related data along with related-demographic details with no missing information since the start of the epidemic, including all records of polymerase chain reaction (PCR) testing, antibody testing, COVID-19 hospitalizations, vaccinations, infection severity classification per World Health Organization (WHO) guidelines ${ }^{21}$ (performed by trained medical personnel through individual chart reviews), and COVID-19 deaths, also assessed per WHO guidelines ${ }^{22}$. Every PCR test conducted in Qatar, regardless of location (outpatient clinic, drive-thru, or hospital, etc.), is classified on the basis of symptoms and the reason for testing (clinical symptoms, contact tracing, random testing campaigns (surveys), individual requests, routine healthcare testing, pre-travel, and port of entry). Qatar has unique demographics by sex and nationality, since expatriates from over 150 countries comprise $89 \%$ of the population ${ }^{12,23}$.

The nature of circulating SARS-CoV-2 virus was informed by weekly rounds of viral genome sequencing and multiplex, quantitative, reverse-transcription PCR (RT-qPCR) variant screening $^{24}$ of randomly collected clinical samples ${ }^{6,7,9-11}$, as well as by the results of deep sequencing of wastewater samples ${ }^{9}$. The weekly rounds of viral genome sequencing from January 1-May 19, 2021 identified Beta $(n=623 ; 50.9 \%)$, Alpha $(n=193 ; 15.8 \%)$, Delta $(n=43$; $3.5 \%)$, and wild-type/undetermined variants $(n=366 ; 29.9 \%)$ in 1,225 randomly collected, PCR- 
medRxiv preprint doi: https://doi.org/10.1101/2021.07.25.21261093; this version posted July 26, 2021. The copyright holder for this preprint (which was not certified by peer review) is the author/funder, who has granted medRxiv a license to display the preprint in perpetuity.

All rights reserved. No reuse allowed without permission.

positive specimens ${ }^{9,10}$. Meanwhile, the weekly rounds of multiplex RT-qPCR variant screening from March 23-May 10, 2021 identified Beta-like (n=2,605; 66.4\%), Alpha-like ( $n=970 ; 24.7 \%)$, and "other" variants $(\mathrm{n}=349 ; 8.9 \%)$ in 3,924 randomly collected PCR-positive specimens ${ }^{9,11}$. Sanger sequencing of the receptor binding domain of SARS-CoV-2 spike protein on 109 "other" specimens confirmed that 103 were Delta-like, 3 were B.1-like, and 3 were undetermined ${ }^{9,11}$.

All records of PCR testing in Qatar were examined in this study. Every individual that met the inclusion criteria in the national database, that is being vaccinated with BNT162b2 or mRNA1273 and completing $\geq 14$ days after the second vaccine dose, for each of these cohort studies, was classified based on infection status (with or without PCR-positive swab before the start of the study). Individuals were matched based on infection status on a 1:1 ratio by sex, 5-year age group, nationality (>75 nationality groups), and calendar week of first vaccine dose to control for differences in exposure risk $^{12,13}$ and variant exposure ${ }^{6,7,9-11}$. Only matched samples were included in the analysis.

Further background on Qatar's epidemic, such as on reinfections ${ }^{25,26}$, national seroprevalence surveys $^{12,18-20}$, PCR surveys ${ }^{12}$, and other epidemiological studies can be found in previous publications on this epidemic 6 6,7,12,13,27-34.

\section{Laboratory methods}

Nasopharyngeal and/or oropharyngeal swabs (Huachenyang Technology, China) were collected for PCR testing and placed in Universal Transport Medium (UTM). Aliquots of UTM were: extracted on a QIAsymphony platform (QIAGEN, USA) and tested with real-time reversetranscription PCR (RT-qPCR) using TaqPath ${ }^{\mathrm{TM}}$ COVID-19 Combo Kits (100\% sensitivity and specificity ${ }^{35}$; Thermo Fisher Scientific, USA) on an ABI 7500 FAST (ThermoFisher, USA); extracted using a custom protocol ${ }^{36}$ on a Hamilton Microlab STAR (Hamilton, USA) and tested 
medRxiv preprint doi: https://doi.org/10.1101/2021.07.25.21261093; this version posted July 26, 2021. The copyright holder for this preprint (which was not certified by peer review) is the author/funder, who has granted medRxiv a license to display the preprint in perpetuity.

All rights reserved. No reuse allowed without permission.

using AccuPower SARS-CoV-2 Real-Time RT-PCR Kits (100\% sensitivity and specificity ${ }^{37}$;

Bioneer, Korea) on an ABI 7500 FAST; or loaded directly into a Roche cobas® 6800 system and assayed with a cobas ${ }^{\circledR}$ SARS-CoV-2 Test (95\% sensitivity, $100 \%$ specificity ${ }^{38}$; Roche,

Switzerland). The first assay targets the viral S, N, and ORF1ab regions. The second targets the viral RdRp and E-gene regions, and the third targets the ORF1ab and E-gene regions.

Antibodies against SARS-CoV-2 in serological samples were detected using a Roche Elecsys ${ }^{\circledR}$ Anti-SARS-CoV-2 assay (99.5\% sensitivity ${ }^{39}, 99.8 \%$ specificity $^{39,40}$; Roche, Switzerland), an electrochemiluminescence immunoassay that uses a recombinant protein representing the nucleocapsid $(\mathrm{N})$ antigen for antibody binding. Results were interpreted according to the manufacturer's instructions (reactive: optical density (proxy for antibody titer ${ }^{41}$ ) cutoff index $\geq 1.0$ vs. non-reactive: optical density cutoff index $<1.0$ ).

All PCR tests were conducted at the Hamad Medical Corporation Central Laboratory or Sidra Medicine Laboratory, following standardized protocols.

\section{Statistical analysis}

Descriptive statistics (frequency distributions and measures of central tendency) were used to characterize study samples. Significant associations were determined using two-sided p-values. The Kaplan-Meier estimator method ${ }^{14}$ was used to estimate the cumulative risk of documented infection. Cumulative risk was defined as the proportion of individuals identified with an infection during the study period among all eligible individuals in each cohort.

Incidence rates of documented infection in each cohort were calculated by dividing the number of infection cases identified during the study by the number of person-weeks contributed by all eligible individuals in the cohort. Incidence rates and corresponding 95\% CIs were estimated 
medRxiv preprint doi: https://doi.org/10.1101/2021.07.25.21261093; this version posted July 26, 2021. The copyright holder for this preprint (which was not certified by peer review) is the author/funder, who has granted medRxiv a license to display the preprint in perpetuity.

using a Poisson log-likelihood regression model with the STATA $17.0^{42}$ stptime command.

Follow-up person-time was calculated from the day each person completed 14 days after the second vaccine dose up to the infection swab, all-cause death, or end-of-study censoring (June 6, 2021). The incidence rate ratio and corresponding $95 \%$ CI were calculated using the exact method.

Statistical analyses were conducted in STATA/SE version $17.0^{42}$.

\section{Ethical approvals}

The study was approved by the Hamad Medical Corporation and Weill Cornell Medicine-Qatar Institutional Review Boards with waiver of informed consent.

\section{Data availability}

The dataset of this study is a property of the Qatar Ministry of Public Health that was provided to the researchers through a restricted-access agreement that prevents sharing the dataset with a third party or publicly. Future access to this dataset can be considered through a direct application for data access to Her Excellency the Minister of Public Health (https://www.moph.gov.qa/english/Pages/default.aspx). Aggregate data are available within the manuscript and its Supplementary information. 
medRxiv preprint doi: https://doi.org/10.1101/2021.07.25.21261093; this version posted July 26, 2021. The copyright holder for this preprint (which was not certified by peer review) is the author/funder, who has granted medRxiv a license to display the preprint in perpetuity.

All rights reserved. No reuse allowed without permission.

\section{Supplementary Material}




\section{Supplementary Table 1. STROBE checklist for cohort studies.}

\begin{tabular}{|c|c|c|c|}
\hline & Item No & Recommendation & $\begin{array}{l}\text { Main Text page } \\
\text { no }\end{array}$ \\
\hline Title and abstract & 1 & $\begin{array}{l}\text { (a) Indicate the study's design with a commonly used term in the title or the abstract } \\
\text { (b) Provide in the abstract an informative and balanced summary of what was done and } \\
\text { what was found }\end{array}$ & $\begin{array}{l}1 \\
2\end{array}$ \\
\hline \multicolumn{4}{|c|}{ 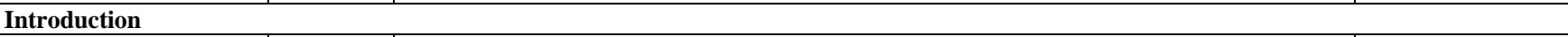 } \\
\hline Background/rationale & 2 & Explain the scientific background and rationale for the investigation being reported & 3 \\
\hline Objectives & 3 & State specific objectives, including any prespecified hypotheses & 3 \\
\hline \multicolumn{4}{|c|}{ 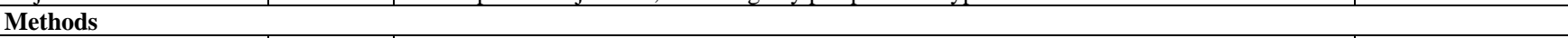 } \\
\hline Study design & 4 & Present key elements of study design early in the paper & 3 \\
\hline Setting & 5 & $\begin{array}{l}\text { Describe the setting, locations, and relevant dates, including periods of recruitment, } \\
\text { exposure, follow-up, and data collection }\end{array}$ & $15-18$ \\
\hline Participants & 6 & $\begin{array}{l}\text { (a) Give the eligibility criteria, and the sources and methods of selection of participants. } \\
\text { Describe methods of follow-up } \\
\text { (b) For matched studies, give matching criteria and number of exposed and unexposed }\end{array}$ & $15-17$ \\
\hline Variables & 7 & $\begin{array}{l}\text { Clearly define all outcomes, exposures, predictors, potential confounders, and effect } \\
\text { modifiers. Give diagnostic criteria, if applicable }\end{array}$ & 16 \\
\hline $\begin{array}{l}\text { Data sources/ } \\
\text { measurement }\end{array}$ & $8 *$ & $\begin{array}{l}\text { For each variable of interest, give sources of data and details of methods of assessment } \\
\text { (measurement). Describe comparability of assessment methods if there is more than one } \\
\text { group }\end{array}$ & $15-16$ \\
\hline Bias & 9 & Describe any efforts to address potential sources of bias & 16 \\
\hline Study size & 10 & Explain how the study size was arrived at & $16 \&$ Figures $1-2$ \\
\hline Quantitative variables & 11 & $\begin{array}{l}\text { Explain how quantitative variables were handled in the analyses. If applicable, describe } \\
\text { which groupings were chosen and why }\end{array}$ & $16-17$ \\
\hline Statistical methods & 12 & $\begin{array}{l}\text { (a) Describe all statistical methods, including those used to control for confounding } \\
\text { (b) Describe any methods used to examine subgroups and interactions } \\
\text { (c) Explain how missing data were addressed } \\
\text { (d) If applicable, explain how loss to follow-up was addressed } \\
\text { (e) Describe any sensitivity analyses }\end{array}$ & $\begin{array}{l}16-17 \\
\text { NA } \\
\text { NA, see p.15 } \\
\text { NA } \\
\text { NA }\end{array}$ \\
\hline \multicolumn{4}{|c|}{ 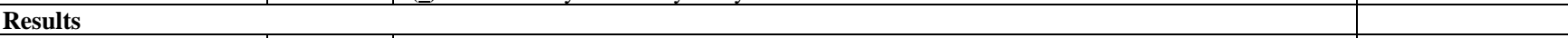 } \\
\hline Participants & $13 *$ & $\begin{array}{l}\text { (a) Report numbers of individuals at each stage of study-eg numbers potentially eligible, } \\
\text { examined for eligibility, confirmed eligible, included in the study, completing follow-up, } \\
\text { and analysed } \\
\text { (b) Give reasons for non-participation at each stage } \\
\text { (c) Consider use of a flow diagram }\end{array}$ & Figures 1-2 \\
\hline \multirow[t]{3}{*}{ Descriptive data } & \multirow[t]{3}{*}{14} & $\begin{array}{l}\text { (a) Give characteristics of study participants (eg demographic, clinical, social) and } \\
\text { information on exposures and potential confounders }\end{array}$ & Table 1 \\
\hline & & (b) Indicate number of participants with missing data for each variable of interest & NA, see p. 15 \\
\hline & & (c) Summarise follow-up time (eg, average and total amount) & Table 1 \\
\hline Outcome data & 15 & Report numbers of outcome events or summary measures over time & $\begin{array}{l}3-4, \text { Figure } 3 \text {, and } \\
\text { Supplementary } \\
\text { Figure } 1\end{array}$ \\
\hline \multirow[t]{3}{*}{ Main results } & \multirow[t]{3}{*}{16} & $\begin{array}{l}\text { (a) Give unadjusted estimates and, if applicable, confounder-adjusted estimates and their } \\
\text { precision (eg, } 95 \% \text { confidence interval). Make clear which confounders were adjusted for } \\
\text { and why they were included }\end{array}$ & $\begin{array}{l}3-4 \text {, Figure } 3 \text {, and } \\
\text { Supplementary } \\
\text { Figure } 1\end{array}$ \\
\hline & & (b) Report category boundaries when continuous variables were categorized & 16 \\
\hline & & $\begin{array}{l}\text { (c) If relevant, consider translating estimates of relative risk into absolute risk for a } \\
\text { meaningful time period }\end{array}$ & NA \\
\hline Other analyses & 17 & $\begin{array}{l}\text { Report other analyses done - eg analyses of subgroups and interactions, and sensitivity } \\
\text { analyses }\end{array}$ & NA \\
\hline \multicolumn{4}{|c|}{ T } \\
\hline Key results & 18 & Summarise key results with reference to study objectives & $4-5$ \\
\hline Limitations & 19 & $\begin{array}{l}\text { Discuss limitations of the study, taking into account sources of potential bias or } \\
\text { imprecision. Discuss both direction and magnitude of any potential bias }\end{array}$ & 5 \\
\hline Interpretation & 20 & $\begin{array}{l}\text { Give a cautious overall interpretation of results considering objectives, limitations, } \\
\text { multiplicity of analyses, results from similar studies, and other relevant evidence }\end{array}$ & $5-6$ \\
\hline Generalisability & 21 & Discuss the generalisability (external validity) of the study results & 5 \\
\hline \multicolumn{4}{|l|}{ Other information } \\
\hline Funding & 22 & $\begin{array}{l}\text { Give the source of funding and the role of the funders for the present study and, if } \\
\text { applicable, for the original study on which the present article is based }\end{array}$ & Acknowledgements \\
\hline
\end{tabular}

Abbreviations: NA: not applicable; 
medRxiv preprint doi: https://doi.org/10.1101/2021.07.25.21261093; this version posted July 26, 2021. The copyright holder for this preprint (which was not certified by peer review) is the author/funder, who has granted medRxiv a license to display the preprint in perpetuity.

All rights reserved. No reuse allowed without permission.

Supplementary Figure 1. Kaplan-Meier curves showing the cumulative incidence of documented SARS-CoV-2 infection in the national cohort of individuals who completed $\geq 14$ days after the second vaccine dose and who had a prior PCR-confirmed infection, compared to the cumulative incidence of documented SARS-CoV-2 infection in the matched national cohort of individuals who completed $\geq 14$ days after the second vaccine dose, but without prior PCR-confirmed infection. The curves compare vaccination with A) the BNT162b2 (Pfizer-BioNTech) vaccine and B) the mRNA-1273 vaccine. Cohorts were matched in a 1:1 ratio by sex, 5-year age group, nationality, and calendar week of the first vaccine dose. The cumulative infection incidence among the BNT162b2-vaccinated persons, with and without prior infection, was estimated at $0.16 \%(95 \%$ CI: $0.11-0.23 \%)$ and $1.45 \%$ (95\% CI: 1.20-1.76\%), respectively, after 132 days of follow-up.

A

Vaccination with BNT162b2

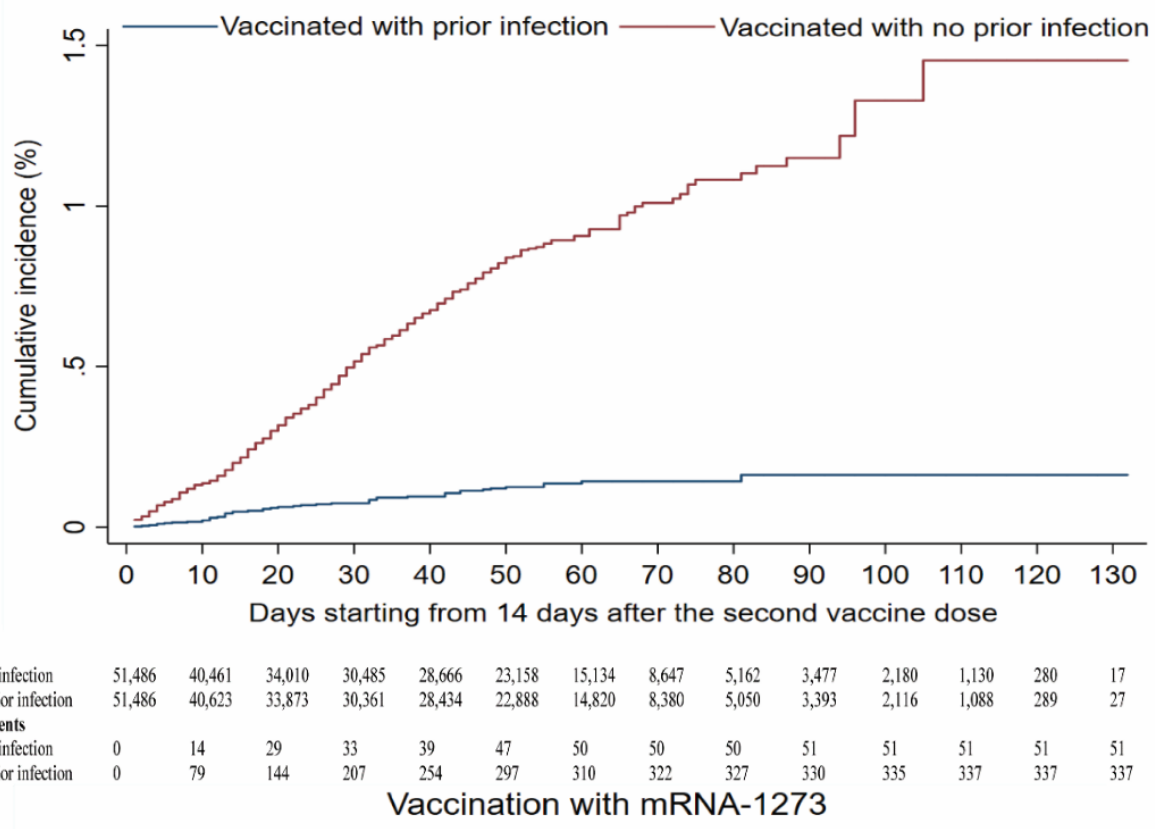

B

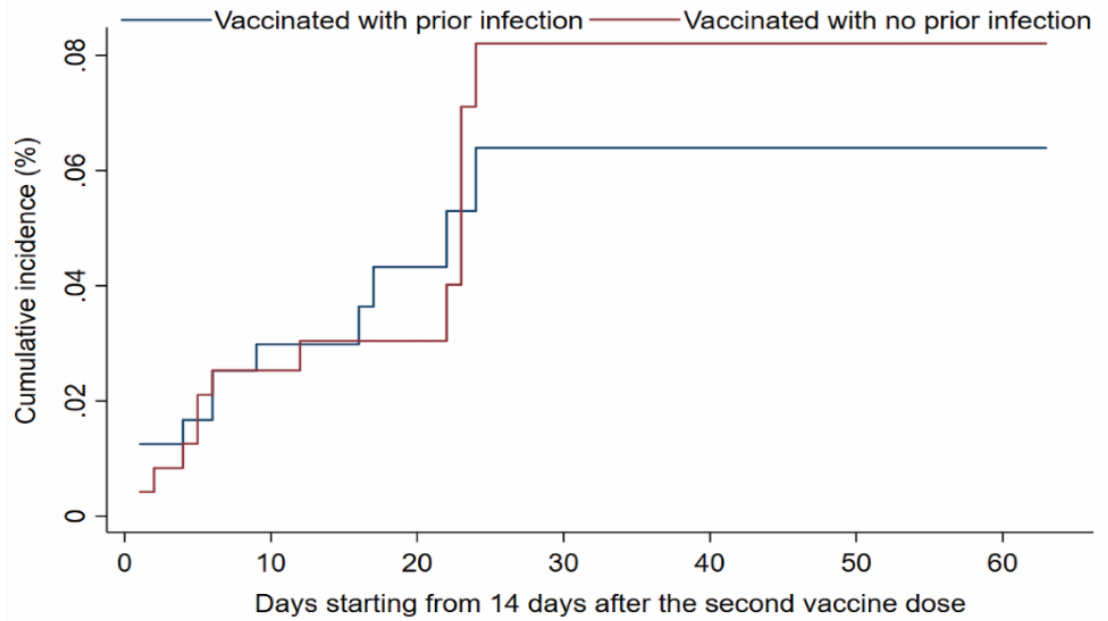

No. at risk

Vaccinated with no prior infection 24,052

Cumulative No. of events

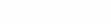

from

Vaccinated with prior infectio

21,094
21,219

11,830
11,866

4,903
4,989
11

363
366
11
13

$\begin{array}{ll}173 & 33 \\ 169 & 40 \\ & \\ 11 & 11 \\ 13 & 13\end{array}$

